\title{
Intrepid or Invisible? Female Characters in Catalan Children's and Young Adult Literature
}

\section{Abstract:}

This article analyses 95 children's and young adult literature works written originally in Catalan and published between 2002 and 2006. They are representative of all age groups present in this genre. This analysis focuses on the presence or absence of female characters, and on their treatment and reception, both in terms of prominence and the transmission of stereotypes. The results of this review show a dichotomy between the scarcity of female protagonists and their extreme audacity.

Key words:

Catalan literature, children's and young adult literature, children's historical fiction, female protagonists, feminist criticism, intercultural education, literary education

\section{Nieustraszone czy niewidzialne? Bohaterki katalońskiej literatury dziecięcej i młodzieżowej}

\section{Abstrakt:}

W artykule autor poddaje analizie 95 tekstów literatury dziecięcej i młodzieżowej napisanych oryginalnie w języku katalońskim, wydanych między 2002 a 2006 rokiem i skierowanych do wszystkich grup wiekowych w ramach omawianego gatunku. Praca skupia się na obecności lub braku w opracowanych materiałach postaci kobiecych, a także na ich odbiorze i sposobie przedstawienia, zarówno w kontekście wagi odgrywanej roli, jak i utrwalania stereotypów. Jak wynika z przeprowadzonej analizy, uwagę zwraca rozbieżność między deficytem kobiecych bohaterek a ich niezłomnym heroizmem.

\section{Słowa kluczowe:}

literatura katalońska, literatura dziecięca i młodzieżowa, powieść historyczna dla dzieci, postaci kobiece, krytyka feministyczna, edukacja interkulturowa, edukacja literacka

* Xavier Mínguez López - PhD, works at the Department of Language and Literature Teaching at the University of València (Spain). His research interests include children's and young adult literature, as well as the comprehension of animation (with a special focus on Japanese animation) and literary education. He is a co-director of the Journal of Literary Education. Contact: xavier.minguez@uv.es. 
Introduction

hildren's and young adult literature in Catalan suffers from a lack of academic inquiry from a feminist approach, and, even more evidently, of one applied to a corpus. Indeed, the works by Anna Díaz-Plaja $(2008,2011)$ and Consol Aguilar $(2006,2008)$ are undoubtedly great contributions, however this paper is the most comparable to the works of Teresa Colomer (1998) and Xabier Etxániz (2004): the former carried out a comprehensive analysis of the corpus of international literature taking into account gender and, especially, the presence and representation of female protagonist characters. As for Etxániz, his corpus was limited to a single year of children's and young adult literature written in Basque, that is to 1994, therefore it is not entirely or completely comparable here. For the corpus, I selected works of children's and young adult literature originally written in Catalan. Although the comparisons between the two aforementioned studies are not entirely analogous, I can draw some important conclusions from them.

As Lissa Paul (1987) describes, the feminist approach to children's and young adult literature is especially interesting since "there is good reason for appropriating feminist theory to children's literature. Both women's literature and children's literature are devalued and viewed as marginal or peripheral by literary and educational communities" (p. 186). Indeed, both were persecuted and ostracised in literary institutions and continue to be peripheral in our society. Therefore, the methodology of many feminist authors is easily transposable onto literary criticism of children's and young adult literature. If we take as an example the images of women in literature (Moi, 1995), we see that a study of the images of children would also be very valuable to literary criticism, sociology, and pedagogy. The debate about the existence (or inexistence) of a feminine style (Showalter, 2009) is clearly linked to the discussion and the continued research on the existence of a style that is inherent in children's literature. Other more theoretical aspects, as Deborah Thacker (2000) explores, like "the notion of the imposition of the symbolic order (or the patriarchal law of language) on the imaginary (or a female/maternal space) can be extended to include the process by which we are constructed, in a continuum that begins in childhood, as subjective beings" (p. 6). Without delving into it, and on a finishing note, I cite the notions of silence, negation, and the infantilisation of the child by the adult-based society.

Therefore, it is especially striking that feminist criticism, like the other schools of literary criticism, has noticeably ignored children's literature. Thacker (2000) offers several reasons as to why this relationship should indeed be 
considered. On the one hand, this is because the feminist theory has offered abundant support to enquiries surrounding "children's literature and on the other hand, if the proximity of this literature to the domestic sphere can contribute to its marginalization, so too does the notion of silencing the Other, whoever or whatever this may be, enrich what can be said about texts for children" (p. 6).

As Roderick McGillis (2010/2011) says, "feminist literary criticism has opened up the previously slim canon of children's books" (p. 156), including authors who are not well-known, hidden, and/or deemed inferior. In a similar way, Sonja K. Foss (2017) asserts that "feminist scholars recognize that incorporating feminist perspective into rhetorical studies could do nothing less than transform the discipline" (p. 146). In addition, the feminist approach provides us with a stimulating perspective on ideology in literature and other poststructuralist perspectives make it possible to extend the analysis to other areas of literary study. Taking everything into consideration, the feminist literary criticism has opened up many possibilities for research and analysis, both for children's literature and for literature in general.

\section{Methodology and Corpus}

This study includes 95 works written originally in Catalan (see Appendix: Analysed Corpus, Tables 5-9). For this reason, translations have been discarded, although in the case of translations from Spanish it has been difficult as sometimes authors may alternate the languages in which they write, or two languages (i.e. Spanish and Catalan) can be used simultaneously within the same publishing house. Works of foreign authors were also removed to facilitate an in-depth analysis of children's literature in Catalan.

The study of female figures is included in a wider investigation that takes into account the presence of interculturality in children's literature in Catalan (Mínguez-López, 2016). This explains the temporal scope (2002-2006) that corresponds to the highest peak of immigration in the country. This broadly defined interculturality (Abdallah-Pretceille, 2001; Aguado Odina, 2003; Dervin, 2016; Mínguez-López, 2010) appeals to diversity, including gender diversity (the presence of both genders) and is one of the most relevant aspects that measure an author's intent and motivation to create literature that reflects a multicultural reality. I also applied an intersectional perspective (Davis, 2016; Phoenix, 2006; Prins, 2006) since diversity cannot only be related to the axis of social power but also to the nested assemblages of forces producing shifting 
social positions and identities. It is necessary to include in an intercultural analysis other dimensions such as gender, ethnicity, religion, etc.

The books in this corpus were selected following a triple criterion. Firstly, I included works that had received prestigious awards; secondly, those that had earned positive reviews in Faristol and CLIJ journals, and thirdly, those that had been selected in the lists of honour of the aforementioned periodicals. I have not included works from other lists of honour and journals because I considered the criterion of territorial representation that originally appeared to be essential. These three criteria were used to select about twenty works per year, distributed equally between age groups to proportionally represent the territories of the Catalan language. Thus, most of the works selected for this study have won one or more awards; have earned positive reviews; and/or have been highlighted in the aforementioned journals.

To come closer to a better understanding of the works, I will take into account the classic categories coined by Mary Ellman (1968). These being indecision, passivity, instability, confinement, piety, materiality, spirituality, irrationality, and complication. Although I did not apply them systematically here, they had an indispensable influence on my analysis. In this article, I will focus on the presence of female protagonists, co-protagonism of both male and female protagonists, as well as the presence and representation of female characters in the works in general, as did Teresa Colomer (1998) and Xabier Etxániz (2004). I want to emphasize, however, that the showed percentages are merely a suggestion, since in many cases they do not reflect accurately what a book conveys in all its complexity. The primary method of analysis has, therefore, been a close reading from a feminist perspective, very similar to what in the tradition of interculturality is called "to read interculturally" (Mínguez-López, 2010). I also echo Lissa Paul's (1987) proposal of "re-reading" (p. 142) as there is little reinterpretation in the corpus. The rest of her so-called categories cannot be applied to this corpus.

Indeed, I also use approaches to the study of ideology since, in the words of Charles Sarland (1999), ideology "is not a separated concept 'carried by the texts,' but [...] all texts are inevitably infused by ideologies” (p. 30). Robyn McCallum and John Stephens (2010), in fact, point out that:

Our grounding assumption is that all aspects of textual discourse, from story outcomes to the expressive forms of language, are informed and shaped by ideology, understanding ideology in its neutral meaning as a system of beliefs which a society shares and uses to make sense of the world, and which are therefore intrinsic in the texts produced by that society (p. 360). 
For children to have a place in the society and acquire some personal decision-making procedures of their own, they must learn to understand and negotiate various meanings emerging from the society to navigate through life. All this naturally involves the perspective of gender. In the words of Paul (1987), "[c]ritics who work in feminist theory, postcolonial studies and children's literature all find themselves interested in common grounds: in the dynamics of power, in ideology, in the construction of the subject" (p. 151).

I will begin my analysis by considering the presence and absence of female protagonists and characters. I will then focus on the specific issues pertaining to the historical novel. Next, I will analyse examples from books where the selection of gender is both irrelevant and the author's conscious choice. Finally, I will discuss the paradoxes of female protagonism and gender mixed pairs, which I have labelled as the paradigm of the intrepid in face of the invisible.

\section{Female Protagonists}

The first element that immediately stands out in the corpus concerns the representation of protagonists. $54.7 \%$ of the examined books feature male protagonists compared to only $17.8 \%$ with female ones (see Table 1 ). In this dramatic situation, I should add that $26.3 \%$ of books portray shared co-protagonism (see Table 1), half of them involving male characters who incorporate a female into the action, typically in a pair or with a female who will eventually become a partner. If we considered these cases as examples of male protagonism, as they indeed were considered in this study in the face of the secondary position of women, then the figure would rise from $54.7 \%$ to over $70 \%$.

TABLE 1. Gender of the protagonists according to my study,

Teresa Colomer (1998), and Xabier Etxániz (2004)

\begin{tabular}{|l|c|c|c|}
\hline $\begin{array}{c}\text { Gender } \\
\text { of protagonists }\end{array}$ & $\begin{array}{c}\text { Current study } \\
(\mathbf{2 0 0 2 - 2 0 0 6 )}\end{array}$ & $\begin{array}{c}\text { Colomer } \\
(\mathbf{1 9 7 7 - 1 9 9 0 )}\end{array}$ & $\begin{array}{c}\text { Etxániz } \\
(\mathbf{1 9 9 4 )}\end{array}$ \\
\hline Male & $54.7 \%$ & $62.8 \%$ & $60.61 \%$ \\
\hline Female & $17.8 \%$ & $29.5 \%$ & $18.1 \%$ \\
\hline Both & $26.3 \%$ & $7.7 \%$ & $21.21 \%$ \\
\hline Indeterminate & $1.2 \%$ & & \\
\hline
\end{tabular}

In this comparative table - and I insist that comparisons should be made with all possible reservations as they are from different corpora - we can observe 
a real diminishing in the presence of females as the protagonists, whose representation has practically been reduced almost by a half with respect to the other studies; a phenomenon which is also observed in children's and young adult literature written in Basque.

\section{The Case of the Historical Novel}

Before moving on to the analysis of the works as a whole, I will analyse the case of the historical novel, which besides representing an important percentage of the corpus (24.2\%, see Table 2), also provides the measure of a naturalisation of gender differences, especially for male protagonists. Naturalisation can be understood as the social construction of gender and other roles as 'natural' or innate of a given group (Garner \& Grazian, 2016). Thus, male protagonism remains the unmarked term of opposition and is naturalised through contexts that have typically relied on the presence of male protagonists (Colomer \& Olid, 2009; Olid, 2009).

Female protagonists are reduced by half in this group, whereas male protagonists increase considerably. In the Middle Ages, for instance, it may have been more 'natural' for a man to take the initiative; to practise a trade or have an occupation; or to set out on a journey, etc. Nonetheless, this does not necessitate a male protagonist. It is entirely possible that the gender could be reversed without tarnishing the quality or credibility of the plot. The selection of gender is therefore an 'evitable' choice or decision.

TABLE 2. Male and female protagonists in the historical novel

\begin{tabular}{|c|c|c|c|}
\hline Genre & $\begin{array}{c}\text { Male } \\
\text { Protagonist }\end{array}$ & $\begin{array}{c}\text { Female } \\
\text { Protagonist }\end{array}$ & Both \\
\hline Historical novels (24.2\%) & $65.4 \%$ & $11.6 \%$ & $23 \%$ \\
\hline
\end{tabular}

Assuming that the historical adventure novel must have a male protagonist, this protagonism is naturalised in many other contexts too. Additionally, it is very common in the historical works of the corpus (23\%, see Table 2$)$ that women appear as a reward for the protagonist once he is victorious. This paradigmatic case can be seen in Gent de pedra [The Stone People] (Huertas, 2003), in which the protagonist defeats the wizard of the Neolithic village to win a girl that was offered to him if he were to beat the wizard. Whether or not these 
events may have taken place, this is still a reconstruction that is not necessarily historical:

'I myself am a present from Fut, my father, for the Great Wizard. He freed me because he wanted to help Arbitzan protect his family. Now I belong to him. [...] all the women he has are presents; it is the reward that Arbitzan claims for the protection offered to the Stone People. And you too, Sun Man, you are his' (Huertas, 2003, p.74).

'Sun Man has slept with Bera!' Arbitzan's words began to take effect. People were starting to become uncomfortable, confused. 'Bera is impure! Set her alight! If we want to recover the fertility of the fields, if we want good harvests, we must destroy the seed of evil!' (Huertas, 2003, p.170)1.

In another novel, Un riu d'espigues [A River of Spikes] (Ballart, 2005), we find that the protagonist's role as a priestess restricts, if not prohibits, her from abandoning the male protagonist. Therefore, her escape happens symbolically when the Roman people bow down to her. After the description of the scene where Abania gazes upon the new king with adoration, the author closes the story with this fragment:

And Abania, while smiling and caressing Tibaste with her gaze, understood that the breath of the legend was transcending beyond that singular scene, as she stood there calm and compliant, so that the memory and the voice of all those citizens who were so proud of her would be able to retell it many times, in every corner of Ilercavonia and far beyond; to recount that fortunate day in the city of Tivissa, while so much expected devastation invaded the country, Tibaste, the head of the Iberian lands, was able to keep at bay the Wolf's throat far from the whole town (Ballart, 2005, p. 149).

In this novel, moreover, everything revolves around the journey that both protagonists must embark upon in which Tibaste is the protector and Abania the protected.

To preserve an element of historicism in the works, while maintaining realism, some avoid solutions offering a much less stereotyped vision of the woman. This is the case, for example, at the end of L'esclau del Mercadal [The Slave of Mercadal] (Garcia i Cornellà, 2004), in which the idea of the traditional family can be observed:

\footnotetext{
1 Translations are made by the author of the paper - Xavier Mínguez López.
} 
Alamanda was not going to be a nun in a nunnery. [...] Two years later, she married a farmer from San Gregorio with whom she had four children, two boys and two girls, but only one girl reached adulthood [...]. The daughter of Alamanda was called Sibilla, and when it was time, she married a well-renowned doctor from Girona. Alamanda lived for many years peacefully, surrounded by her daughter, her son, and three grandchildren, on the farmhouse of Sant Gregori (Garcia i Cornellà 2004, p. 197).

The book continues with other similar life stories, which perpetuate a certain image of women and family life that were perhaps mostly representative of the time, but certainly not the only ones.

It must be mentioned, however, that the role of women in these books is not that of a mere spectator. Even in the works where we would expect a conduct of this nature, the authors offer, or at least attempt to offer, representations of the female gender that extend beyond their role as a final reward to be won or an object of contemplation. Thus, in A River of Spikes, we could expect a completely passive role from an Iberian priestess, who must be escorted to another city. But Abania actively participates in the care of Tibaste when he falls ill; has her own opinions; and valiantly faces the vicissitudes that follow them. Additionally, the noblewoman in Al-Razhes, el metge de la talaia [Al-Razhes, the Doctor of the Watchtower] (Oliver, 2006) takes an active part in the flight of the protagonist and, as a priestess, asserts her role when facing everybody.

Sometimes, in these works, women take this active role by exercising the power traditionally granted to them through links with home and family. A perfect example of this is found in El rei dels senglars [The King of the Wild Boars] (Garcia Llorca \& Tha, 2003) where, in agreement with the children, the mothers force the fathers to negotiate a situation, instead of fighting. Also, in a similar way, women in El silenci del mariner [The Silence of the Sailor] (Oliver, 2002) are in charge of everything that concerns the child and anything related to it. In El tresor dels maquis [The Treasure of the Maquis] (Constans, 2006), widowed women are the driving force of the families within their economic and educational framework. These women, without being the protagonists of the story or contributing much to the central plot, appear as secondary characters full of strength and courage. Although it is not the main and active role we would wish for, it is always a more positive vision than that of presenting the female gender as a supporting character. 


\section{Protagonism and the Role of the Female in Catalan Children's and Young Adult Literature}

\section{The Invisible}

If we look beyond the historical genre, we see that this relatively valid effort to make stories credible blurs as they progress. There is no reason for the protagonists of books such as Operació tarrubi [Operation Tarrubi] (Broseta \& Infante, 2002), El Naïm s'ha descolorit [Naïm Have Faded] (Rimbau \& Gutiérrez, 2006), El nen que feia pondre el sol [The Child Who Set The Sun] (Pastor \& Canals, 2005), etc. to be men and not women. In some cases, as with the twins in Sabor a crim [Taste of Crime] (Casas, 2003), nothing would change if the author were to choose the female twin to narrate the story. The author nonetheless prefers, and opts for, the male one. In these books, there is no character development from a gender perspective. There are no exclusive patterns for men, not even occupations that traditionally have been assigned to men, as the story concerns child protagonists. Thus, gender choice continues to be the choice of the unmarked term of the pair and does not contribute anything positive or negative.

In other cases, there may be an ideological motivation, possibly unconscious in the terms outlined by Robyn McCallum and John Stephens (2010). This would be the case of El tresor del vell pirata [The Treasure of the Old Pirate] (Molist \& Clariana, 2002), where a grandfather shares with his grandson the secret of the existence of a treasure on an island that he does not remember. From a more traditional point of view, it seems more reasonable that the grandfather shares this secret with his grandson; a secret as attached to the male imagination as the world of pirates. Additionally, and again from a traditional point of view, it is reasonable to expect that it is a male descendant who goes to find his bandit ancestor in A carn, a carn! ${ }^{2}$ (Pradas, 2002) since, from this perspective, he could have more characteristics commonly used to describe an outlaw than if it were a girl. Guillot in Terramolsa (García Llorca, 2004) is more fitting as a male character than as a female one since he is an outlaw. It is that way even though his masculine name derives from the noun guilla [vixen] which is feminine in Catalan, like others colloquial animal names (e.g. la rabosa or la guineu). I do not subscribe to these values, but it is important to search for an explanation for such an overwhelming representation of male protagonists.

\footnotetext{
2 “A carn!" was the attack signal for bandits in the $18^{\text {th }}$ Century.
} 
Books that take advantage of this male protagonism are noteworthy as well. It is the highpoint of Jo el desconegut [I, the Stranger] (Dalmases, 2005) in which a very well-constructed portrait of a male teenager is painted. In this case, we find that the choice here is not coincidental, as the author's intention to work consciously with the personality of a character with male characteristics is evident. It must be noted that the author achieves this well, as we can see in the following fragment concerning the inner thoughts of the protagonist, when he reveals his jealousy towards a doctor:

'Once again that guy! It seemed very clear that I couldn't shake him off.'

'What on earth has that got to do with anything? This doctor is a friend of yours,' I underlined the possessive with scorn [...]

'Arnau, if you want to be more intense, I think you could not,' he continued in line with feeding my self-esteem, 'don't you understand that Ramon's delusions have a personal, very intimate, psychological basis?'

When he talked to me about psychology, I lost patience. All that was missing was him proposing that I go to see the school psychologist, a woman of angelic appearance, almost juvenile, who smiled continuously looking into space, and who when she spoke, always began with "at the level of," and that was the nickname with which everyone knew her by.

'At the level of what ...?', I replied (Dalmases, 2005, p. 62).

Another case in which this takes place, or at least for which there is an explanation for the choice of a male character, is L'herència [The Inheritance] (Cela \& Tubau, 2005). In this book, the character in charge of bequeathing a particular inheritance is a mouse, and we find another case of a male character tasked with looking after children, a cat. It is funnier because he is depicted as a male character that is used to living a life without responsibilities and no obligations, much like a stereotypical single male TV character who finds himself unexpectedly with a family.

A negative example of the conscious choice of gender that is in some way justified - though from a conservative perspective - can be found in Capità $i$ el gos orgullós [Captain and the Proud Dog] (Bertran \& Miquel, 2005). The protagonists of this story are two male street dogs. The justification for this gender selection is relevant to the plot, which consists specifically in the conquest of the neighbourhood bitches by these canine 'Latin lovers.' Indeed, to develop a plot with these traits, two males as protagonists would be required. In addition, one of them is disabled, which could help assist with the issue of integration and representation of these group, but straying away from this objective, and in face of the challenges of conquering a high-class bitch, Captain, 
the protagonist, is reminded that he should not forget that he is out of her league. Thus, he seeks the company of another dog more in line with his status, in particular, a bitch which is described as "pretty ugly, with a fallen ear and the other upright, but as kind as a mushroom omelette [sic]" (p.78). This shocking description of the narrator complements a more conservative, sexist, and even discriminatory ideological profile of the disabled community.

I could multiply the examples of books where male protagonism does not contribute anything to the plot other than playing the part of unmarked opposition, as it was said before, but I will continue with the vision of female protagonists.

\section{The Intrepid}

In many of the works with female protagonists, the qualities of the female protagonists are indisputable and show courage, which is beyond that of the masculine protagonists who are more varied from this perspective. Table 3 offers a percentage of intrepid women (75\%) and female characters with unmarked roles.

TABLE 3. Intrepid female protagonists and unmarked roles

\begin{tabular}{|c|c|c|}
\hline Protagonism & Intrepid (women) & Unmarked roles \\
\hline Female protagonists (17.8\%) & $75 \%$ & $25 \%$ \\
\hline
\end{tabular}

I would like to consider the example of Maria from Els llops de la lluna roja [Wolves of the Red Moon] (Delgado, 2009). Just as the novel begins, she is attacked by a pack of wolves and saved in extremis by a Republican army military squad. The same wolves approach her house and her mastiff strays away attracted by a she-wolf in heat. Fearing for her dog, Maria follows the wolves and goes after her mastiff, tracking them all over the Pyrenees: she walks without rest, eats raw meat - showing her valour; gets frostbite in one of her feet, etc. In the end, we find out that it was Maria, now old, who is the narrator of this story, which is told in a much more conventional way. The impression the reader has when reading the novel is that of an extremely brave and resistant little girl. However, in Maria's case, I must take note of the slight modality of the narrator who does not offer an exaggerated account of her exploits, but rather that Maria is carried away by the circumstances imposed on her to save her dog.

Another example of courage is that of the protagonist in Les veus protectores [The Protective Voices] (Bogunyà, 2004). Not only does her family die but she has 
to fight to save herself from the harassment of the paramilitary groups scattered all over the place where she took refuge. Her final decision also shows her fighting spirit as she decides to emigrate and study to help her people fight injustice. In a similar line, Selma of Història d'amor a Sarajevo [Love Story in Sarajevo] (Benavente, 2005) is the one who provides for her family as a taxi driver in the dangerous streets of her city at war, since her parents were unable to do so.

The protagonist of El desert de gel [The Ice Desert] (Carranza, 2006) also shows courage although, given that this is a fantasy novel, it may not have the same effect on the reader as the hyper-realistic stories that I have just highlighted, as this is typically reserved for protagonists in adventure stories. In this way, Selene reveals her courage during her dangerous journey across Iceland while pregnant and practically kidnapped by Gunnar, her partner. Selene manages to overcome the dangers that surround her, from Gunnar's betrayal to the pursuit of rival witches, and even to the descend to the depths of death to demand justice for her and her daughter. The fact that it is a novel about witches turns it into a women's book in some way, since the protagonists are all women, who live connected and, at times, even in a community where they pass on their knowledge from mothers to daughters. The presence of a man like Gunnar, also magical, is the antithesis of this feminine society. Additionally, this character, it must be mentioned, moves into action at the same time as fulfilling the requirements for a demigod. His description, in fact, makes us think of a top model:

He fascinated me. He had the appearance of a prince and the majesty of a god. Tall, with brown skin and blue eyes like steel. He was armed with his shield and his sword, and upon his blond, long hair the horns of his helmet pierced fiercely [...]. Then he looked into my eyes and offered me his hand. My legs trembled. This had never happened to me. The Viking Warrior was radiant, and I was hypnotised (Carranza, 2006, p.52).

This apparent submission of Selene to Gunnar must be understood in the context of semi-mythical characters. Gunnar is ultimately revealed as an ancient Viking Warrior equal to Selene.

Books with a younger or child protagonists have heroines who also face dangers in relation to their size. An obvious case is that of Princess Aluci from Mei-Mei vol ser rei [Mei-Mei Wants to be a King] (Viana \& Baldó, 2005), who sets out to recover the family jewels stolen by the dragon Mei-Mei. This quest, unlike others, does not cause any uproar within the family, as this time it is the princess who is predestined: 
'But... after what you've told me, I think I have to retrieve the family jewels.' 'And I will go with you,' said the king.

'No, father. Nobody shall accompany me. Remember what godmother said. I will go alone, and I will return to you what is yours,' Aluci replied with the seriousness of an old man (Viana \& Baldó, 2005, p.41).

This is how this little girl walks all alone and faces various dangers, duly infantilised by the author, with only the help of another woman, a fairy who gives her advice on how to overcome the dangers.

Paquita, the lamb from the book of the same name, L'ovella Paquita [Paquita the Lamb] (Farré, 2005), lives in a world of women (ewes) and rebels against the sedentary lifestyle and passivity of her flock. She, however, is not in danger, she wants to grow as a person (or as a sheep) thanks to a process of acculturalisation and a widening of her knowledge of the world. For Yung, a character from Kor de parallamps [Lightning Rod's Heart] (Sotorra, 2006), knowledge is also a way of embarking on a journey of personal development. More than confronting danger, what Yung faces is the misfortune suffered by her older brother on his trip to Africa. As in La Torre [The Tower] (Villatoro \& Rius, 2006) which we shall see later, in Kor de parallamps there is also a type of female protagonism which exists but appears passive in the shadow of her brother. That said, it is not as strong here, because, alongside her brother's accident, Yung-Moon reflects upon her everyday life as well.

To complete this picture of active and committed women and girls, I highlight an example aimed at younger children. In the album Sóc molt Maria [I am Very Much Maria] (Anguera \& Piérola, 2002), the protagonist rebels in her own way against the imposition of social norms that she must follow as a princess. Unconsciously, she ruins a dress and some accessories that her family picked out for her to go to her aunt's wedding. It ends with a reassessment of her personality, as described in the title of the book: "I am Very Much Maria." This album, however, is not free of its pitfalls. Though it criticises social norms, it presents a tremendously conventional family model. On the other hand, to reaffirm the rebellious personality of the girl, the author keeps her image invisible throughout the book and only reveals her true identity in the last illustration. Indeed, this is intended to have a humorous and surprising effect on the reader, and what goes beyond my assessment is this rebellious and contemptible vision of the girl. However, it is clear to us that in some cases it is very difficult to opt for a particular representation of women without encountering a multitude of different interpretations. Thus, my analysis and commentary always consider work on the texts and not so much the search of texts that convey the desired values. 


\section{Shared Protagonism / Protagonists}

Table 4 shows books with share protagonism. As mentioned earlier, half of these books include a female companion of the leading male character, which can be problematic.

TABLE 4. Books with shared protagonism

\begin{tabular}{|c|c|c|c|c|}
\hline \multicolumn{1}{|c|}{ Protagonism } & $\begin{array}{c}\text { Predominant } \\
\text { male } \\
\text { protagonist }\end{array}$ & $\begin{array}{c}\text { Predominant } \\
\text { female } \\
\text { protagonist }\end{array}$ & $\begin{array}{c}\text { Shared } \\
\text { protagonist }\end{array}$ & $\begin{array}{c}\text { Indetermi- } \\
\text { nate } \\
\text { protagonism }\end{array}$ \\
\hline $\begin{array}{l}\text { Books with shared } \\
\text { protagonism }(26.3 \%)\end{array}$ & $37.6 \%$ & $12.5 \%$ & $33.3 \%$ & $16.6 \%$ \\
\hline
\end{tabular}

In Animals! (Bolta \& Ruiz, 2002), this role, embodied by the wife of the leading man, involves a series of stereotypes surrounding women, presented as interested only in money, dresses, luxury, etc. At the same time, however, we find that the 'wives' of the animals are those who are responsible for the important decisions of this group. Both the lioness and the female elephant are intelligent and wise, unlike their male animal counterparts such as the lion, which is revealed in the first line of the book. The responsibility of maintaining the modus vivendi, the traditions, and the basic principles which makes the animals what they are, falls upon the females. This could very well be considered from an opposite point of view: the woman as a messenger of family values and traditions. In the context of the novel, however, this vision is confronted, on the one hand, with the economic perspective of neo-colonialism represented by humans, while on the other, it involves the defence of the values of animals in the face of their own extinction and the consumerism that contributes to it. This is an example of a different bias that a feminist reading can assign to a work.

In other works where protagonism is shared, it is much easier to detect the features that are used to portray an inferior position of women: invisibility, submission, sensitivity to action, etc. An example of this is found in L'escola secreta de Madame Dudú [The Secret School of Madame Dudú] (Colom, 2002) where one of the storks responsible for bringing a baby to a village in Africa suffers an accident and ends up at the house of a single Italian painter who takes care of them both. The positive a priori view of a man who takes care of a baby collapses immediately when it is shown that he is useless when taking on the tasks essential for paternity with some other deeds that, in addition to 
putting him in danger, show his clumsiness, which is fortunately relieved by the good work of the stork. The president of France, who also happens to take care of other two babies, is not as lucky:

'But you cannot miss out on the cradling nights or the days walking the girls through the Tulleries!' Madam Dudú clearly scandalised as he spoke to her. They were very close.

'Of course!' The president admitted. 'But I would like to take them to the circus, and watch parades. Oh! And also to the wax museum and the tomb of Napoleon!' 'But soon you will be the butt of all jokes, and the press will be full of it. I do not want to even think about the rubbish the opposition parties would say,' so warned the circumspect Monsieur Huló.

Madame Dudú was clear about it.

'What you need is somebody to lend you a hand, day to day. A nanny of trust who knows everything about the little creatures. And, above all, so that you are not interrupted in the middle of a state meeting, by somebody who asks you what colour lace they should wear, or when they need to have some growth syrup!' (Colom, 2002, p. 127).

The plot, with the storks that go to a special school to prepare for this task and the humorous tone of these details, can explain the presence of such sexist affirmations, but I do not think they justify them. Even more if we find other samples of this bias such as the characterisation of Madame Dudú who knowing that she has to visit the president, shows no other concern than about what she is wearing.

The classic attraction of a man to a woman is also a common theme in these pairs of protagonists. It is observable in El darrer manuscript [The Last Manuscript] (Galícia, 2005), Un riu d'espigues [A River of Spikes] (Ballart, 2005), Un petó de mandarina [A Kiss of Tangerine] (Canal \& Ruano, 2006), Els caçadors del sol [The Sun Catchers] (Oliver, 2005), L'embruix d'una guitarra cordovesa [The Spell of a Cordovan Guitar] (Barrufet \& Soldevila, 2006), and Quan tot comença [When Everything Starts] (Pons \& Clar, 2006). In all these examples, the leading man embarks on an adventure or is led by a co-protagonist woman, although the action continues to mainly involve the man. So, despite the fact that both genders appear as protagonists, in reality, what we see is a protagonist assisted by a woman who acts as an accompanying person, even if she intervenes actively during some moments but without assuming at any time the protagonism at the same level as a man. A striking example of this is that women do not adopt the voice of the narrator, nor is the omniscient narration ever focused on them. 
We also find some examples in which the protagonist is the female part of the couple. Vull una corona [I want a Crown] (Portell \& Blanch, 2005) is a fantastic example of this female protagonism where we see that it is the girl who teaches the king how to act. Furthermore, the protagonist of Història d'un cap tallat [History of a Cut Head] (Garcia Llorca, 2004) is the woman who carries the story, both with the orders she gives to her friend, and in part due to her role as a woman with the magical powers of water. An interesting inversion of this theme occurs in L'aposta [The Bet] (Nel-lo, 2002). Here the undisputed protagonist is the little boy, Sègol (literally "Rye," inspired by The Catcher in the Rye by J. D. Salinger, 1952), who has to win a bet by seducing a woman older than he is. But the woman, Lupe, turns out to be much more seductive and interesting than he had anticipated and eventually becomes a major character in the story to the point of establishing conditions of the relationship and, consequently, of the story itself. This also transpires in Els colors de la memòria [The Colours of Memory] (Romaní Cornet \& Romaní Cornet, 2006), in which the gender perspective is equally complex in its analyses since the role of the painter is predominant throughout the story in the past when the painter taught Mariona how to paint. However, in the present, it is Mariona who asserts herself more as a protagonist over her current partner.

In this line of a certain complexity regarding the gender perspective, $L a$ Torre [The Tower] (Villatoro \& Rius, 2006) is also relevant. The protagonist is the daughter of the engineer Gustave Eiffel. She is the narrator of the story and, when her father dies, she continues to recount her personal experiences which are not greatly relevant, since the central point is, in fact, the story of her father and the construction of the Eiffel Tower. Thus, what we see is a narrative focused on Gustave Eiffel with a narrator who is at the same time a protagonist and a witness. In this way, the positive feature of female protagonism is buried under the constant eulogy of the father, the story's main protagonist par excellence.

In Aiguablava (Mollà \& Bosch, 2006), an internal contradiction regarding the treatment of gender can also be found. The protagonist, Celeste, proclaims herself as the Princess of Aiguablava (a fictitious name for Lake Albufera). After a big argument with her father who does not let her go camping because she is a girl, she rebels and decides to take the silver path that is visible from the window of her room and finally enter Aiguablava. There she has to face four disasters that trouble the lake. Before going to sleep, she thinks about her friend Nico and about a shell that her teacher gave her, who swore that by holding the shell close to her heart and saying Nico's name three times, he would appear. Celeste does this almost unconsciously and the next day Nico appears in Aiguablava to help her. 
Celeste faces the dangers of her quest only when she can rely on the help of a boy. A boy who, additionally, is a Red Knight, while she is a princess. In fact, this continues to perpetuate the traditional clichés of a princess who cannot take the initiative and requires the help of a knight. It can be argued that the undeniable protagonist of the story is the girl, and this coincides with the most precipitate part of the story. Nonetheless, what I want to highlight here is the difficulty in dealing with gender issues without falling back, in one way or another, on some of the most common stereotypes in traditional literature.

Like the protagonist of Aiguablava, most of the other female protagonists of the books in the corpus are active women who make decisions and keep going on adventures, often at their own peril. Obviously, it is a feature associated with protagonism, but these features stand out in a special way since in the corpus there is no example of a female protagonist that lets herself be carried away, except perhaps the one in A l'altra banda del mirall [On the Other Side of the Mirror] (Sierra and Fabra, 2008) and the co-protagonist of Mysteries SL (Gisbert, 2004). In the former example, this is easily explained by the development of the plot in which Maria is not clear about her psychosexual identity and is somehow carried away by the circumstances and what is expected of her. Thus, her self-awareness and her assumption that she is a lesbian become so powerful that she has to leave behind her passivity. The second example is a woman who depends on another woman, her aunt. This is yet another instance of a somewhat peculiar educational duo, as her aunt is the detective instructor of her niece.

\section{Conclusions}

As I said at the beginning of this article, the analysis of the contemporary corpus paints an uninspiring image. If we compare it to the work of Teresa Colomer (1998), we can even talk of involution, at least in the subject of the presence of girls and women as protagonists in children's literature. Compared to Colomer's data, the percentage of female protagonists has declined by half, and I believe that this is important enough to draw serious attention to this phenomenon.

The reasons for male leadership are rarely justified and necessary to the plot. In general, they are marked by the traditions of the genre - with the excellent example of the historical novel - by social conventions, and in many 
cases, it is completely unnecessary because a gender switch would not distort the work in the slightest.

On the contrary, which Colomer also foresaw, feminine figures tend to be masculinised to have a part in this leadership role. In the many examples of the few in which there are female protagonists, we see women and girls who fight courageously against the forces of nature or against dangers that are apparently overwhelming. Both tendencies are present in the corpus. Although we find the predominance of male protagonists, in the cases where women are protagonists, they make sacrifices and efforts far above those made by their male counterparts.

As for female co-protagonists, it should be said that, except for some examples such as those highlighted in my analysis, they are not habitually passive. They participate in the action and they do it both with the attributes traditionally associated with their gender, and with much less conventional attitudes. A telling example of this in the corpus is that no women work exclusively as housewives.

Also striking is the emergence of clearly sexist tendencies in some of the analysed books. Striking, because literature for children and pre-schoolers is typically subjected to different, and often stricter, educational control and it is bizarre that such sexist tropes and ideas pass through publishing houses' filters.

This is significant because, although feminist activism in the 1970s had an immediate influence on the works of that decade and beyond as Colomer's (1998) work shows, its influence appears to be weakening while at the same time other societal forces, which assume that this feminist need for demands and campaigns is over, are strengthening. The truth is that, apart from the political position that must be adopted to aspire to real equality, the analysis of the works makes it very clear that we are far from having achieved equality, and we find ourselves in a state of regression regarding the presence and role of women in artistic forms such as children's and young adult literature. I am not talking about the revitalisation of ideological works that seek to campaign for equality (and often end up as anecdotal), but rather of seeking a more real equality with a demand for better representation and protagonism. Neither the percentages nor the roles that appear in the books coincide with the actual presence of women in our society. It is not, then, about a demand, but, simply and plainly, about depicting reality. 


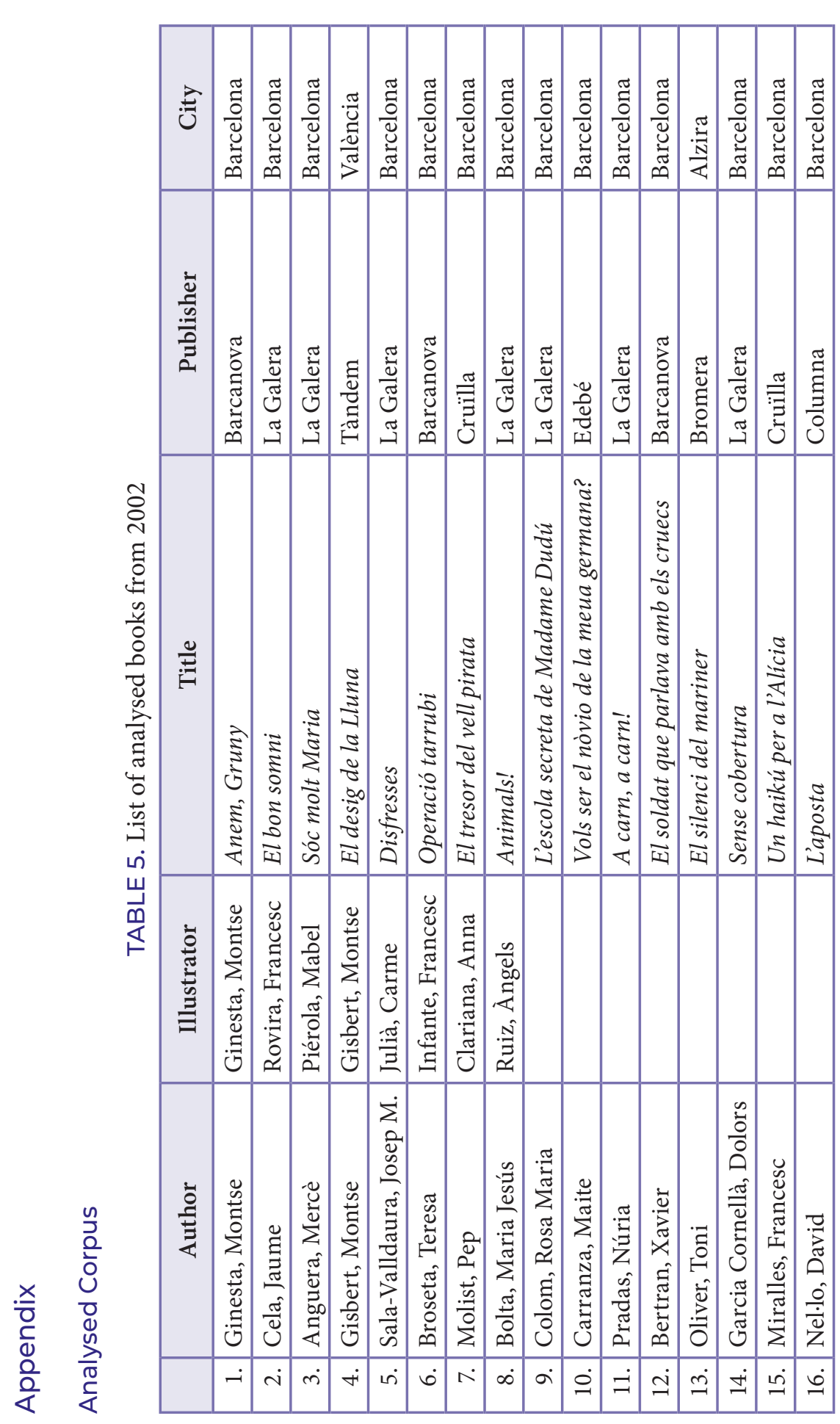




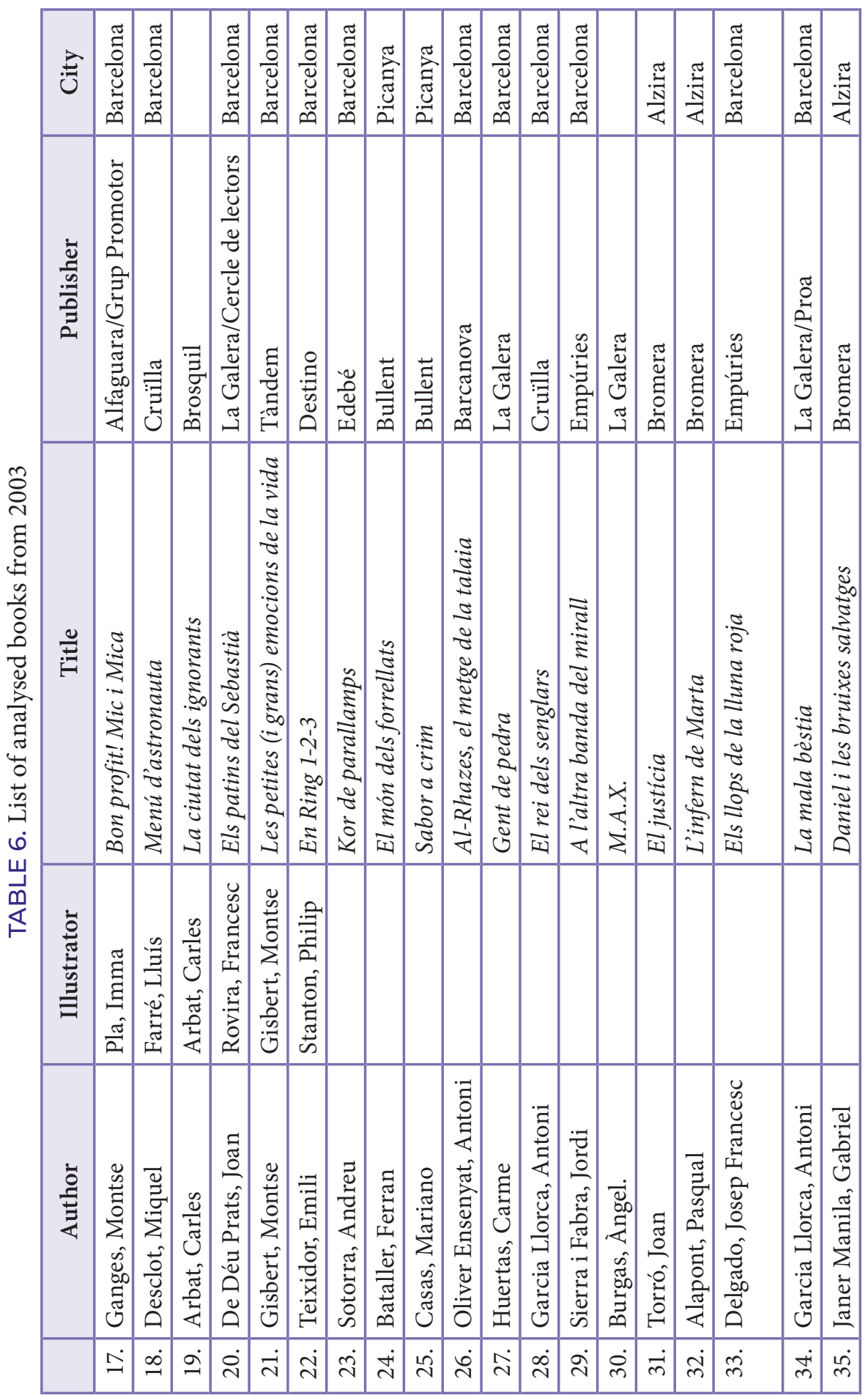




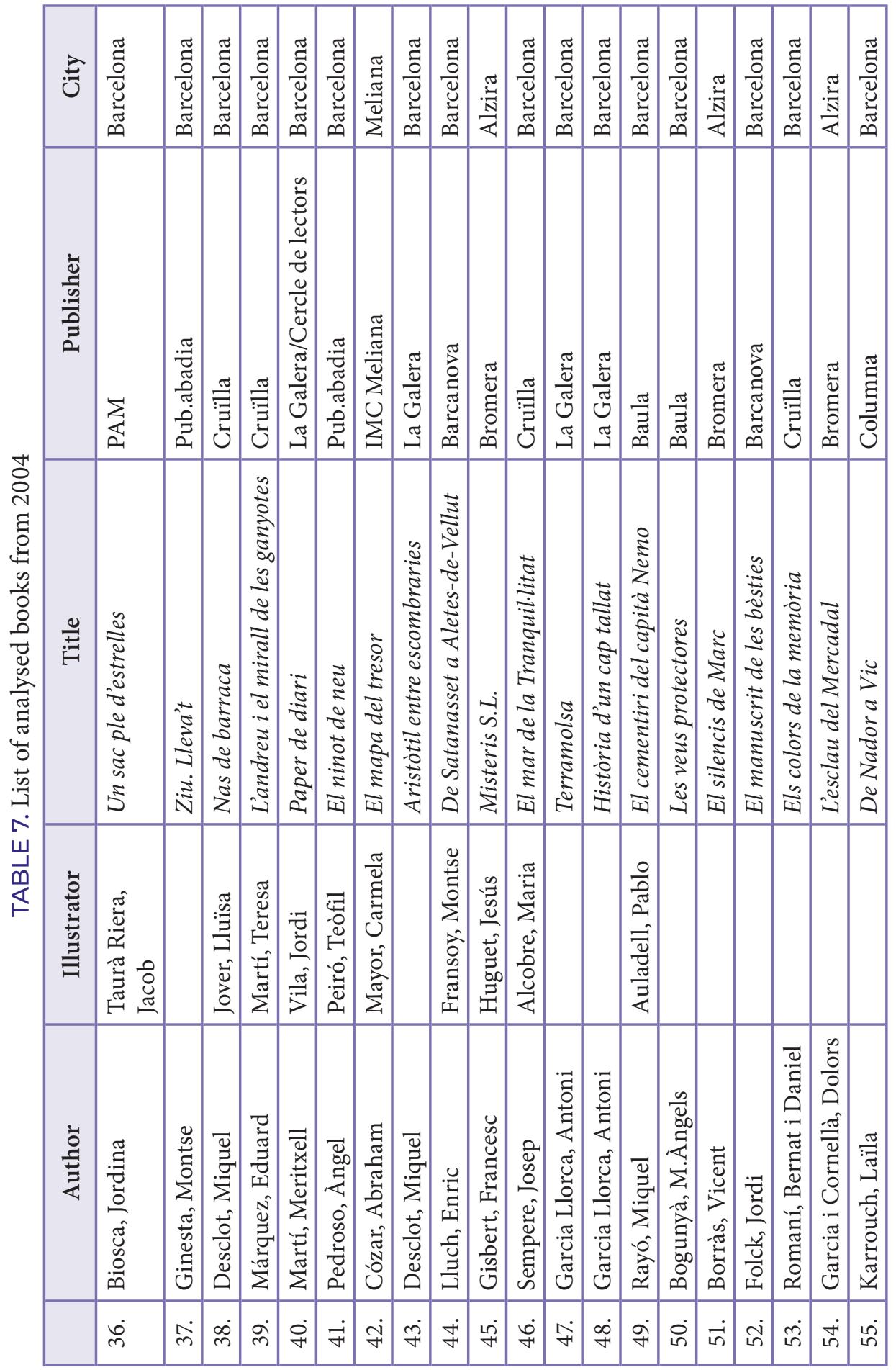




\begin{tabular}{|c|c|c|c|c|c|c|c|c|c|c|c|c|c|c|c|c|c|c|c|c|c|}
\hline$\stackrel{\overrightarrow{0}}{0}$ & 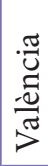 & 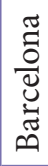 & 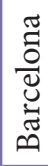 & 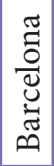 & 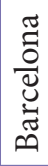 & 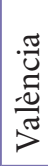 & $\frac{\pi}{\mathbb{N}}$ & 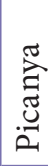 & $\begin{array}{l}\stackrel{\mathbb{Z}}{\Xi} \\
\stackrel{\Xi}{\mathbb{\Xi}}\end{array}$ & 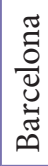 & 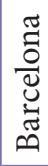 & 苞 & $\frac{\pi}{\mathbb{N}}$ & 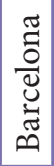 & 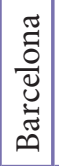 & 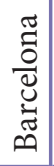 & & 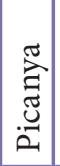 & 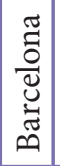 & 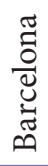 & 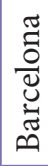 \\
\hline 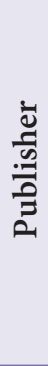 & 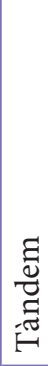 & 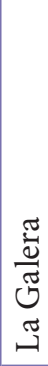 & $\begin{array}{l}0 \\
0 \\
\tilde{0} \\
\text { - }\end{array}$ & 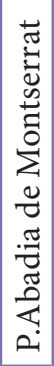 & 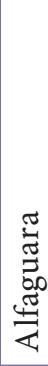 & 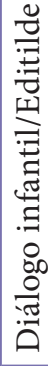 & | & 莞 & 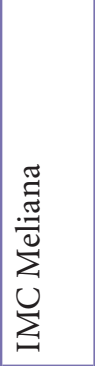 & $\underset{J}{ٍ}$ & 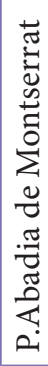 & 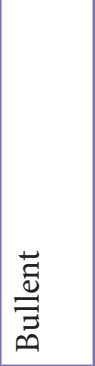 & 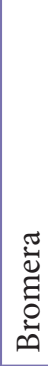 & 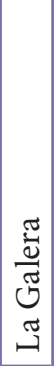 & 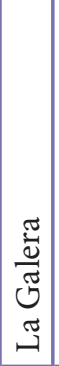 & 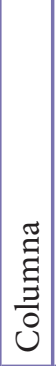 & 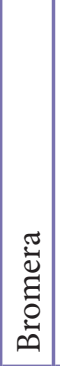 & 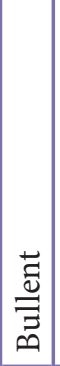 & 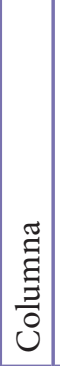 & $\underset{J}{\Xi}$ & 范 \\
\hline$\sum_{\dot{E}=}$ & 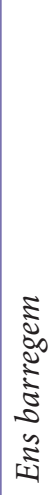 & $\begin{array}{r}5 \\
\frac{5}{2} \\
5 \\
0 \\
0 \\
0 \\
0 \\
0 \\
0 \\
0 \\
0\end{array}$ & $\begin{array}{c}0 \\
0 \\
\frac{0}{0} \\
0 \\
0 \\
\vdots \\
\vdots \\
\vdots \\
5\end{array}$ & 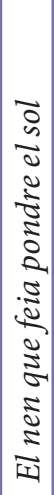 & 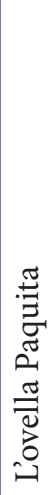 & 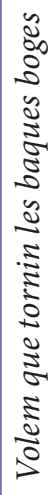 & 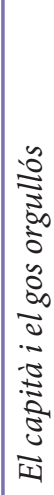 & 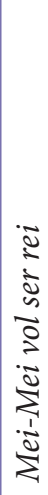 & 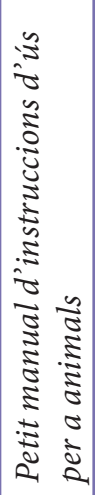 & 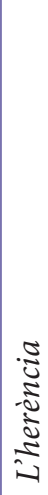 & 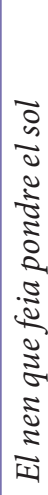 & 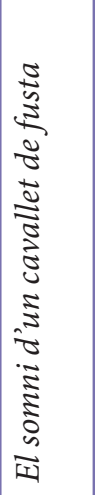 & 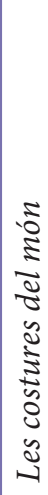 & 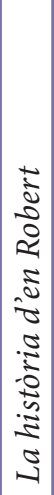 & 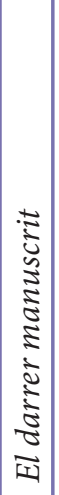 & 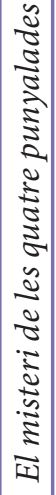 & 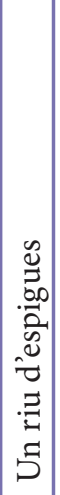 & 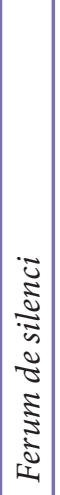 & 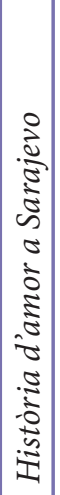 & $\Sigma$ & 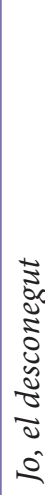 \\
\hline 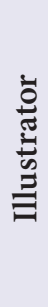 & & 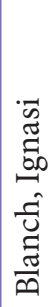 & 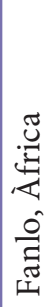 & 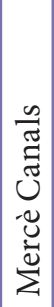 & 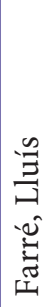 & 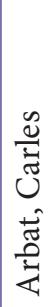 & 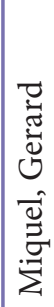 & 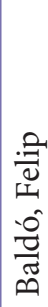 & 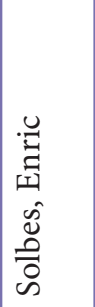 & 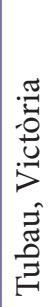 & 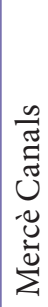 & 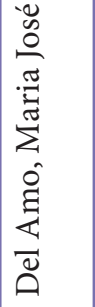 & 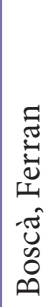 & & & & & & & & \\
\hline 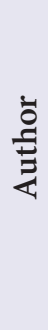 & $\begin{array}{l}\text { 응 } \\
\text { 胥 }\end{array}$ & 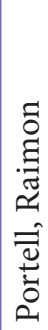 & 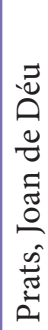 & 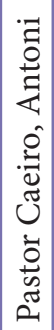 & 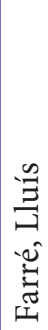 & 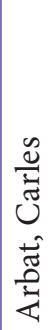 & 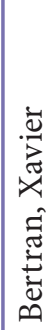 & 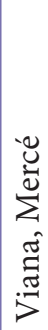 & 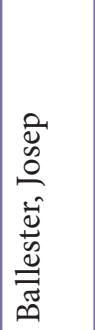 & 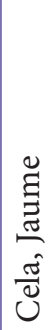 & 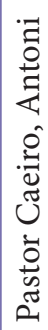 & 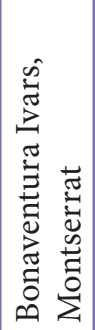 & 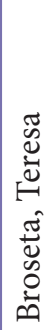 & 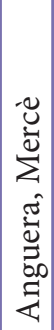 & 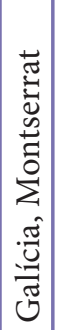 & 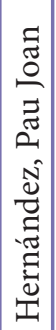 & 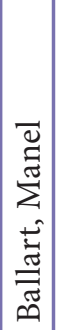 & 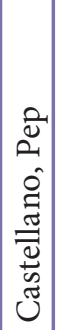 & 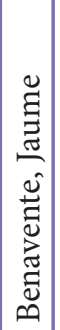 & 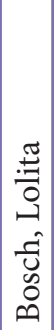 & 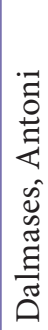 \\
\hline & ம் & in & $\stackrel{\infty}{\circ}$ & ค่ & ஜ் & $\dot{\sigma}$ & ชิ & $\dot{\sigma}$ & تु் & 10 & 6 & $\hat{6}$ & $\infty_{0}^{\circ}$ & $\dot{0}$ & $\dot{R}$ & $\dot{\lambda}$ & $\stackrel{i}{N}$ & $\dot{r}$ & $\stackrel{\mathbb{N}}{\mathbb{N}}$ & ம் & $\stackrel{\bullet}{\curvearrowleft}$ \\
\hline
\end{tabular}




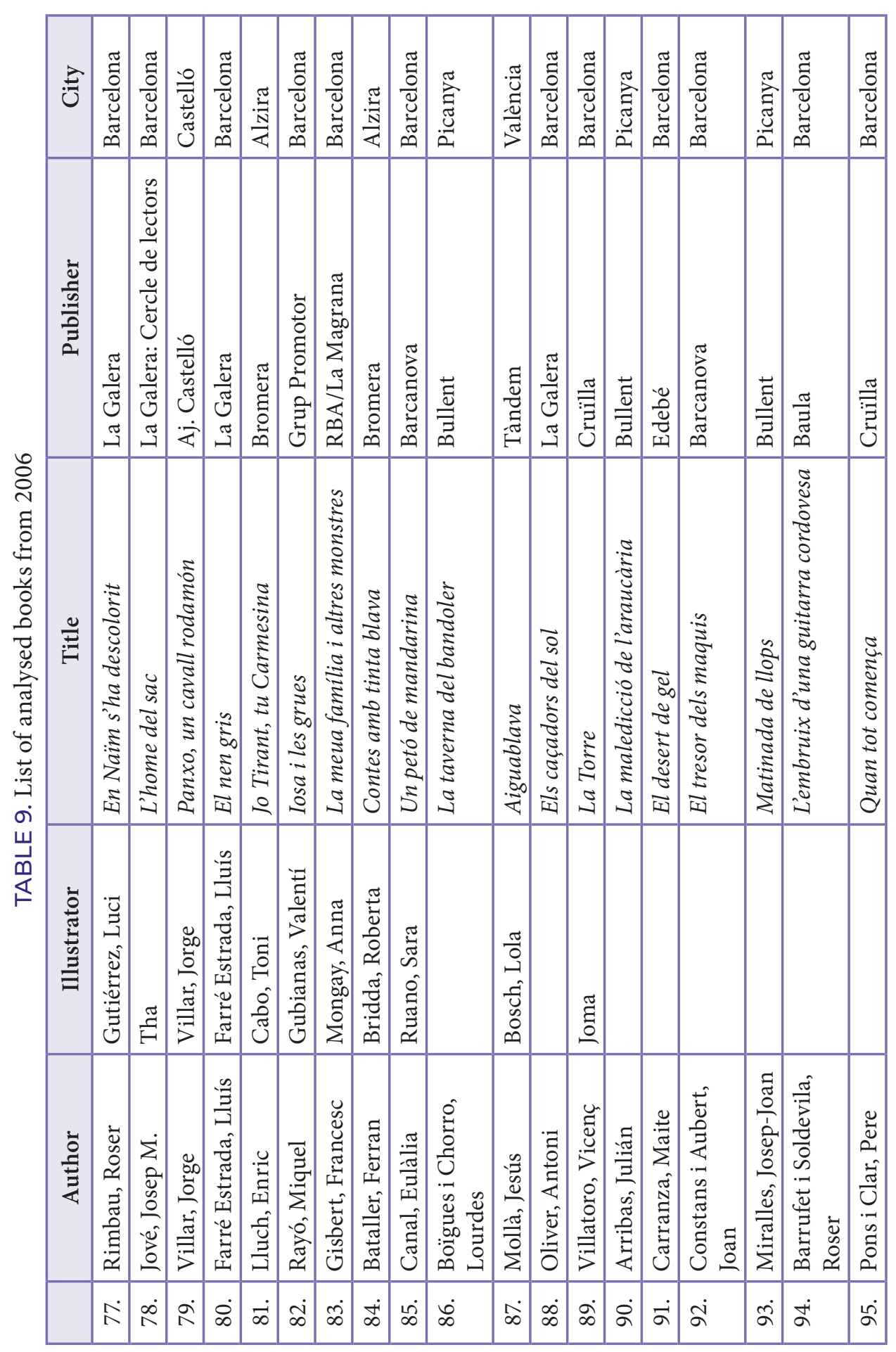




\section{References}

Abdallah-Pretceille, M. (2001). La educación intercultural. Barcelona: Idea Books. Aguado Odina, M. T. (2003). Pedagogía intercultural. Madrid: McGraw-Hill. Aguilar, C. (2006). Género y formación de identidades. CLIJ, 191, 7-15. Aguilar, C. (2008). Lectura, género, feminismo y LIJ. Lenguaje y Textos, 28, 113-128. Anguera, M., \& Piérola, M. (2002). Sóc molt Maria. Barcelona: La Galera. Ballart, M. (2005). Un riu d'espigues. Alzira: Bromera.

Barrufet, R. (2006). L'embruix d'una guitarra cordovesa. Barcelona: Baula. Benavente, J. (2005). Història d'amor a Sarajevo. Barcelona: Columna. Bertran, X., \& Miquel, G. (2005). El capità i el gos orgullós. Alzira: Bromera. Bogunyà, M. À. (2004). Les veus protectores. Barcelona: Baula.

Bolta, M. J., \& Ruiz, À. (2002). Animals!. Barcelona: La Galera.

Broseta, T., \& Infante, F. (2002). Operació tarrubi. Barcelona: Barcanova.

Canal, E., \& Ruano, S. (2006). Un petó de mandarina. Barcelona: Barcanova.

Carranza, M. (2006). El desert de gel. Barcelona: Edebé.

Casas, M. (2003). Sabor a crim. Picanya: Bullent.

Cela, J., \& Tubau, V. (2005). L'herència. Barcelona: Cruïlla.

Colom, R. M. (2002). L'escola secreta de Madame Dudú. Barcelona: La Galera.

Colomer, T., \& Olid, I. (2009). Princesitas con tatuaje: Las nuevas caras del sexismo en la literatura juvenil. Textos. Didáctica de la Lengua y la Literatura, 51, 55-67.

Colomer, T. (1998). La formació del lector literari. Barcelona: Barcanova.

Constans, J. (2006). El tresor del maquis. Barcelona: Barcanova.

Dalmases, A. (2005). Jo, el desconegut. Barcelona: Cruilla.

Davis, L. J. (2016). Introduction: Normality, power and culture. In Davis, L. J. (Ed.), The Disability Studies Reader ( ${ }^{\text {th }}$ rev. ed., pp. 1-14). New York, NY \& London: Routledge.

Delgado, J. F. (2009). Els Llops de la lluna roja. Barcelona: Estrella Polar.

Dervin, F. (2016). Interculturality in education: A theoretical and methodological toolbox. London: Springer.

Díaz-Plaja, A. (2008). Claves de análisis de las novelas para niñas: Valoración histórica y literaria. Unpublished $\mathrm{PhD}$ thesis. Universitat de Barcelona, Spain.

Díaz-Plaja, A. (2011). Escrito y leído en femenino: Novelas para niñas: Análisis y valoración en su contexto. Cuenca: Ediciones de la Universidad de Castilla-La Mancha.

Ellman, M. (1968). Thinking about women. New York, NY: Harcourt, Brace \& World. Etxániz, X. (2004). La ideología en la literatura infantil y juvenil. Cauce, 27, 83-96. Farré, Ll. (2005). L'ovella paquita. Barcelona: Alfaguara, Grup Promotor.

Foss, S. K. (2017). Rhetorical criticism: Exploration and practice. Long Grove, IL: Waveland Press. 
Galícia, M. (2005). El darrer manuscrit. Barcelona: La Galera.

Garcia i Cornellà, D. (2004). L'esclau del Mercadal. Alzira: Bromera.

Garcia Llorca, A. (2004). Història d'un cap tallat. Barcelona: La Galera.

García Llorca, A. (2004). Terramolsa. Barcelona: La Galera.

Garcia Llorca, A. \& Tha (2003). El rei dels senglars. Barcelona: Cruilla.

Garner, B., \& Grazian, D. (2016). Naturalizing gender through childhood socialization messages in a Zoo. Social Psychology Quarterly, 79(3), 181-198.

Gisbert, F. (2004). Misteris S.L. Alzira: Bromera.

Huertas, C. J. (2003). Gent de pedra. Barcelona: La Galera.

McCallum, R., \& Stephens, J. (2010). Ideology and children's books. In S. Wolf, K. Coats, P. Enciso, \& J. Christine (Eds.), Handbook of research on children's and young adult literature (pp. 359-372). New York, NY \& London: Routledge.

McGillis, R. (2011). Literary studies, cultural studies, children's literature, and the case of Jeff Smith. In S. Wolf, K. Coats, P. Enciso, \& J. Christine (Eds.), Handbook of research on children's and young adult literature (pp. 345-358). New York, NY \& London: Routledge. (Original work published 2010).

Mínguez-López, X. (2010). Interculturalidad, multiculturalidad o localismo: un modelo para la LIJ catalana. In J. Herrera Cubas, M. Abril Villalba, \& C. Perdomo López (Eds.), Estudios sobre didácticas de las lenguas y sus literaturas: diversidad cultural, plurilingüismo y estrategias de aprendizaje (pp. 559-572). Sevilla: Servicio de publicacions Universidad de Sevilla.

Mínguez-López, X. (2016). La interculturalitat a la literatura infantil i juvenil catalana. Caplletra. Revista Internacional de Filologia, (61), 61-89.

Moi, T. (1995). Sexual/textual politics: Feminist literary theory. London \& New York, NY: Routledge.

Molist, P. \& Clariana, A. (2002). El tresor del vell pirata. Barcelona: Cruilla.

Mollà, J. \& Bosch, L. (2006). Aiguablava. València: Tàndem.

Nel.lo, D. (2002). L’aposta. Barcelona: Columna.

Olid, I. (2009). Entre chicos y chicas: La fuerza de los estereotipos. La nueva "chick lit” para adolescentes. In A. Díaz-Plaja \& T. Colomer (Eds.), Lecturas adolescentes (pp. 169-184). Barcelona: Graó.

Oliver, A. (2002). El silenci del mariner. Alzira: Bromera.

Oliver, A. (2005). Els caçadors del sol. Barcelona: La Galera.

Oliver, A. (2006). Al-Rhazes, el metge de la talaia. Barcelona: Barcanova.

Pastor, A., \& Canals, M. (2005). El nen que feia pondre el sol. Barcelona: Publicacions de l'Abadia de Montserrat.

Paul, L. (1987). Enigma variations: What feminist theory knows about children's literature. Signal, 54, 186-201.

Phoenix, A. (2006). Interrogating intersectionality: Productive ways of theorising multiple positioning. Women, Gender \& Research, 2-3, 21-29. 
Pons i Clar, P. (2006). Quan tot comença. Barcelona: Cruilla.

Portell, R., \& Blanch, I. (2005). Vull una corona. Barcelona: La Galera.

Pradas, N. (2002). A carn, a carn!. Barcelona: La Galera.

Prins, B. (2006). Narrative accounts of origins: A blind spot in the intersectional approach?. European Journal of Women's Studies, 13(3), 277-290.

Rimbau, R., \& Gutiérrez, L. (2006). En Naïm s'ha descolorit. Barcelona: La Galera.

Romaní Cornet, B., \& Romaní Cornet, D. (2006). Els colors de la memòria. Barcelona: Cruilla.

Salinger, J. D. (1951). The catcher in the rye. Little and Brown: New York, NY.

Sarland, C. (1999). The impossibility of innocence: Ideology, politics, and children's literature. In P. Hunt (Ed.), Understanding children's literature (pp. 39-55). London \& New York, NY: Routledge.

Showalter, E. (2009). A literature of their own: From Charlotte Brontë to Doris Lessing. London: Virago.

Sierra i Fabra, J. (2008). A l'altra banda del mirall. Barcelona: Empúries.

Sotorra, A. (2006). Kor de parallamps. Barcelona: Edebé.

Thacker, D. (2000). Disdain or ignorance? Literary theory and the absence of children's literature. The Lion and the Unicorn, 24(1), 1-17.

Viana, M., \& Baldó, F. (2005). Mei-mei vol ser rei. Picanya: Edicions del Bullent.

Villatoro, V., \& Rius, J. M. (2006). La Torre. Barcelona: Cruilla. 